\title{
11 Constructive resistance and the importance of not knowing in transitional justice
}

\author{
Briony Jones
}

\section{Rethinking transitional justice}

There is a significant and compelling body of work on transitional justice that encourages scholars, practitioners and policymakers to rethink the field's assumptions about how best to address large-scale human rights violations of the past. This might be in relation to its liberal vision of transition and democracy (Sharp 2018), the ability of international experts and transitional justice entrepreneurs to generate the change that they want in varied domestic contexts (McAuliffe 2017), or the expectation that transitional justice should bring about closure and reconciliation (Weinstein 2011). I believe that this work should be taken seriously, and that if we wish to think differently about transitional justice, then we must interrogate and reflect on the labels we give to actors whose motivations, actions and impacts we try to understand. On the one hand, transitional justice comprises the mechanisms, interventions and processes of what has been described as the "global norm" (Nagy 2008). We have United Nations (2010) pillars, transitional justice toolkits ${ }^{1}$ and a burgeoning of non-governmental organizations (NGOs) and consultancies to advise and direct transitional justice (Rubli 2012). On the other hand, transitional justice comprises the always incomplete and subjective impulse to reckon with past violence and to find different ways of living together (Weinstein 2011). We have imaginations of future possibilities, calls to unity and debates over what counts as justice or peace. The empirical reality of societies which are embarking on dealing with the past reflects an iterative movement between these two versions of transitional justice mechanisms and incomplete reckoning - which in fact cannot be easily separated.

As a field, transitional justice scholars are seeking new ways of capturing and comprehending the politics of transitional justice in practice. Much of what shapes this politics is the motivations and actions of actors. In this chapter, my focus is on actors who resist, often designated as "spoilers" in the transitional justice literature, but who offer a valuable analytical window into the ways transitional justice can be reimagined. This it to say that "spoilers" - or actors considered to be motivated primarily by a desire to

DOI: $10.4324 / 9781003167280-15$ 


\section{Briony Jones}

block transitional justice - have not yet been fully understood in the transitional justice field. The tendency to dismiss actors assumed to be working against transitional justice means that the label of spoiler obfuscates ongoing and legitimate debates over the nature of past violence and the different ways to address it. This chapter builds on my prior work on resistance and transitional justice (Jones and Bernath 2017a) and combines it with a politics of knowledge lens in order to further strengthen my argument that "resistance" should be taken seriously as an object of inquiry in transitional justice. There is varied work on resistance from different fields, but I use here the work of political geographers, anthropologists and political scientists to understand resistance as socially constructed, meaning that we should try and understand why and how acts are labelled as resistance when others are not. This is connected to a politics of knowledge lens as the latter focuses on how certain forms of knowledge come to prevail over others. By "politics of knowledge" I mean how the recognition of knowledge as (valid) knowledge is political, and what this tells us about the power relations between actors, the legitimacy of different perspectives, and how what we "know" is shaped by context.

Combining these insights, I draw on a case study of Côte d'Ivoire, where supporters of the former president have been labelled as spoilers of transitional justice. After first situating resistance and transitional justice in the literature on the contested politics of transitional justice, I suggest thinking about resistance as a "way of knowing", or rather "not knowing", in relation to transitional justice. I aim to show how analysing "resistance" as socially constructed can point to the necessarily incomplete nature of "knowing" in transitional justice contexts. Going further, I also argue that not knowing is important, as it creates space for divergent and varied voices in transitional justice.

\section{Transitional justice and its politics of knowledge}

Transitional justice is a field defined by porous boundaries between research and practice, between experientially informed and generalized knowledge, between universals and context. As such it is, in its current state, an assemblage of actors, ideas, actions and objects (Jones and Lühe 2021) generating, claiming and responding to various forms of knowledge. The reason this is important is because transitional justice, in practice, is typically a normative endeavour seeking to generate change. This normative project overlaps with, but can be distinguished from, transitional justice as a journey to reckon with the past. The former seeks "truth" in order to settle accounts and seek order, in response to the violence of the past. This implicitly associates a lack of knowledge, or disagreement over how to know the past, with the danger of not moving forward towards peace and justice. The latter version of transitional justice as a journey to reckon with the past cannot be so sure of its end point, or the road that must be travelled to get there. Joining the critiques of 
other scholars who caution against a desire to seek order and closure in the aftermath of large-scale violations of human rights (Schaap 2007), in this chapter I accept the contested politics of transitional justice and argue that they can be better understood through an empirically informed intellectual enquiry on resistance in terms of those who resist, acts of resistance and the objects of resistance.

By seeking change - be it peace, justice, democratic transition - transitional justice is political. Not all change is equal, and not all voices are heard. The "global norm" of transitional justice has been critiqued for its focus on liberal democracy (Sharp 2018), its association with good governance agendas of liberal peace (Sriram 2017) and its marginalization of the voices of the supposed beneficiaries (Madlingozi 2010) as well as of scholars from the Global South (Kagoro 2012). It is hard for transitional justice to escape its reputation as "Western" and "liberal" when, despite the significant role played by Global South experiences in the formation and shaping of the field (Jones and Lühe forthcoming), the flows of money and "expertise" consolidate "knowledge" as internationally mobile, Western-educated and articulated in the language of the toolkits and pillars associated with the United Nations and international NGOs (McAuliffe 2017, p. 180). What we have, then, is a narrowing of the knowledge landscape of transitional justice and the ways that transitional justice advocates tend to "know" the problem of violence and the solution of transitional justice through trials, truth commissions, reparations or institutional reform. This is not to undermine the work which is done in pursuit of justice or the motivations of those actors. Rather, it is to state that debates about the legitimacy of transitional justice have an important knowledge dimension, asking who can speak on behalf of whom, and how monoliths of knowledge can be broken down, where they remain or emerge.

The monoliths of knowledge which have been a target of critique are varied. Kagoro contends that the origins and development of the transitional justice norm are part of a "post-cold war ascendency of particular, culturally laden narratives about history, society, governmentality and justice" (2012, p. 10). He goes on to write of transitional justice's "knowledge imperialism" (p. 12), a term that reflects the substantial debate in the transitional justice literature about the extent to which the "dominant script" (Sharp 2018, p. ix) of transitional justice continues the imbalances, and even violence, of relations between the Global North and the Global South. Indeed, the production of knowledge on and for transitional justice is not a practice that different actors can engage in equally for "only a particular set of people, in a particular set of circumstances, is able to shape the research agenda which in turn informs policies that shape the world" (Nouwen 2014, p. 258).

This leads to a second area of concern and debate, that of the distinction between the "foreign expert" and the "local beneficiary". Local ownership as a lens of critique emerged largely in response to the standardized solutions offered by international actors from the Global North to the Global South, 
which have been critiqued for undermining local ownership in terms of control, process and substance (Sharp 2013). The "local turn" in transitional justice includes work on "justice from below" (McEvoy and McGregor 2008), positionalities and standpoints (Shaw, Waldorf and Hazan 2010), and African transitional justice (Bennett et al. 2012), among others. However, as noted above, the assumption persists of an unequal binary between international "experts" and local "knowledge" although the latter has instrumental value to the experts in relation to policy advocacy. Therefore, any attempt to reclaim, revive or render visible the "local" in transitional justice may still be read as an act of those with epistemic privilege seeking to give back power to those whose voices have been marginalized. Thus, instead of deconstructing which voices are seen to be expert and which are seen to be local in the first place, these critiques invariably assume and perpetuate a problematic "sense of naturalness and inevitability" of transitional justice (Sharp 2018, p. 1) and the positions assigned to its different actors. This has profound effects on the way we think about, and do, transitional justice. These effects are of course complex and not necessarily negative. The important aspect to highlight for the purpose of this chapter is that their very existence narrows the range of permissive ways of understanding past violence and the justice needed to repair it.

One influential debate about expanding the ways of knowing which underpin transitional justice is that of the legal versus non-legal approaches. Earlier work had already called for transitional justice to look beyond the legal (McEvoy 2007) and to consider not only other disciplinary insights from anthropology, psychology and criminology, for example, but also nonlegal mechanisms such as truth commissions, symbolic reparations and traditional forms of healing (Thomson and Nagy 2011). The legalism of transitional justice is perhaps not surprising, as the challenge with early cases of transitional justice, such as in Argentina, was to identify the appropriate legal tool with which to address past human rights violations (Murphy 2017, p. 29). But this has come to be seen as a "hegemonic quality of law" (Campbell and Turner 2008, p. 378) and empirical research has highlighted the ways in which legal practice in tribunals narrows the set of permissible narratives and seeks to solidify the expertise of the law and lawyers (Wilson 2016; Kelsall 2006). The dominant paradigm of transitional justice, crystallized in the global norm, is still seen to focus heavily on civil and political rights and legal remedies to the exclusion of other violations and remedies (Miller 2008; Palmer et al. 2015; Evans 2016).

These monoliths of knowledge need to be broken down because they do not represent the necessarily contested spaces in which transitional justice interventions take place. If the contestation cannot be seen, for example because of a selective approach to violence and/or a desire to seek closure of the past, then this will weigh on the relationship between transitional justice advocates and those who have experienced violence. There is a significant body of work which highlights the necessarily incomplete nature of 
reconciliation in transitional justice contexts. Schaap (2007) warns of the irreconcilability of social conflict and Little (2009) suggests that a contested politics is perhaps more "normal" following past violence. In contrast, transitional justice literature tends to approach resistance as a problem of "spoilerism" or "deviancy" of those unwilling to accept its processes (Jones and Bernath 2017b, p. 3). Understanding the role of resistance as more than spoilerism builds on work which holds that contestation is present and important, and that resistance may point towards other ways of understanding the past violence and how to respond to it. I argue here that resistance reminds us of what we don't know and that recognizing the incompleteness of our knowledge is important for moving towards answering the crisis of legitimacy in transitional justice.

\section{Resistance as a way of not knowing transitional justice}

In previous work on resistance and transitional justice I have found, along with my co-authors and collaborators, that we can make gains in our analysis of transitional justice if we take resistance seriously as an object of enquiry (Jones and Bernath 2017a). This is an important argument to make because resistance, in transitional justice scholarship, is primarily associated with spoilers. This identity of the spoiler is rather one-dimensional, typically based on the assumption that such actors are only interested in self-preservation through disruption of a formal transitional justice process: by "old regime loyalists" (Subotić 2014, p. 135), by a national political leadership against international criminal procedures (Hansen 2014, p. 119) or by "bad" victims who refuse to accept outcomes of transitional justice processes (Hamber and Wilson 2002, p. 45). This has three key effects. First, it assumes that self-preservation is necessary because those actors have something to fear from the process, implying that they must have been involved in past violence and are the potential targets of any criminal or justice-related intervention. This sets up a moral hierarchy between the values of those who resist transitional justice and those who promote it. Second, it casts resistance as a technical problem of process, something to be overcome if transitional justice actors are to succeed in their ambitions. This limits our understanding of what are highly political and contested contexts. Third, it assumes that what are observed to be acts of resistance can be meaningfully understood in sole reference to transitional justice, i.e. that they are motived, above anything else, by responding to a transitional justice intervention and its specific goals.

The implication of these assumptions is that they go on to make transitional justice itself the centre of our analyses. Learning from the "inside-out" work of scholars on transitional justice such as McAuliffe (2017, p. 22), it is more illuminating, however, to start with understanding in their own right the motivations, actors and effects of resistance which may only partly be related to the specific transitional justice intervention being undertaken 
(Jones and Bernath 2017b). For if we begin the other way around - with the transitional justice intervention first and ask who resists it - we may miss valuable insights into other contestations and debates which might overlap with, but can also pre-date or be only tangentially connected to, transitional justice. We might think here, for example, of colonial histories of violence or of the historical marginalization of groups who are either elevated or targeted by a particular transitional justice intervention. To assume that all acts of resistance can be addressed by either neutralizing spoilers or tweaking the transitional justice intervention is short-sighted and continues the problematic "sense of naturalness and inevitability" of transitional justice (Sharp 2018, p. 14). Moreover, "since transitional justice is inherently political and contested, resistance is necessarily present in multiple forms in the empirical unfolding of transitional justice" (Jones and Bernath 2017a, p. 5). We should therefore not see it as abnormal but as something which we expect to find and that can be used to help us to understand different perspectives on violence, peace, truth and justice. Resistance to transitional justice not only questions its processes but shapes them (Salehi 2018) and holds the key to make sense of the empirical unfolding of transitional justice. In doing so we need to see it as more than the desperation of spoilers and more than a problem requiring a technical fix. We should see resistance instead as a way to bring to the surface what we do not yet understand, or know, about transitional justice and its politics.

It is hence useful to think more constructively about the role of resistance in transitional justice. We can think of the attempt to understand resistance as a new lens, a way of knowing how transitional justice plays out in specific contexts and how it is perceived and experienced by the supposed beneficiaries. Resistance reminds us that we do not in fact know violence or justice in their entirety. It reminds us to be humble and to seek as inclusive a dialogue as possible before we can even begin to make claims to know what has happened in the past and how it should be addressed. In the following section, a short example from Côte d'Ivoire will be used to illustrate how this more constructive approach to resistance and "not knowing" can be analytically useful. These reflections will build on previous work I have published on the subject (Jones 2017) and are based on qualitative empirical work undertaken in 2014, as well as ongoing desk-based research on transitional justice in Côte d'Ivoire. The data was generated through semi-structured interviews, observations, and focus groups both in Côte d'Ivoire and with diaspora in the United States and the United Kingdom. ${ }^{2}$

\section{Côte d'Ivoire: knowledge claims and justice politics}

The combat for the liberation of Laurent Gbagbo is a combat for the return of democracy.

$(\text { Interview } 131014 \mathrm{~F})^{3}$ 
Following independence from France in 1960, Côte d'Ivoire was led by Felix Houphouët-Boigny and his Parti Démocratique de la Côte d'Ivoire - Rassemblement Démocratique Africain (Democratic Party of Côte d'Ivoire), which remained the only political party until 1990 . This was seen by many commentators as a time of stability, management of ethnic tensions, and economic prosperity (Diallo 2005). Following the introduction of multi-party politics and Houphouët-Boigny's death in 1993, there was a series of political crises connected to ethnic divisions, regional splits and claims to autochthony (Bah 2010). A civil war in 2002 was followed by the creation of a unity government in 2003, a buffer zone between the north and south of the country, further violence and then finally the signing, in 2007, of the Ouagadougou Agreement. The 2010 presidential elections (postponed from 2005) were supposed to solidify unity within the country and mark a formal end to the peace process. However, contested results in the second round of the presidential run-off elections led to both the incumbent Laurent Gbagbo and his opponent Alassane Ouattara declaring victory. The African Union, the Economic Community of West African States and the United Nations (UN) supported the election of Ouattara amid high levels of post-election violence from 2010-11. The crisis finally ended on 11 April 2011, after the capture and house arrest of Gbagbo.

Interwoven with these events were acts of political violence from 19902011, which produced a variety of victims whose cases were supported by different political parties. Moreover, the decision of the UN Security Council to announce the election result in favour of Ouattara, in direct opposition to the result announced by the Ivorian Constitutional Council which declared Gbagbo the winner, set the stage for ongoing disagreement, resentment and lack of transparency over the election and its result (Bellamy and Williams 2011, p. 832). The significant role of the former colonial power of France and its troops in using force to protect civilians and in the arrest of Gbagbo also "blurred the lines between human protection and regime change ... and [raised questions] about the place of neutrality and impartiality in UN peacekeeping" (p. 835). These controversies have not been helped by a continued narrative of a "victor's justice" for Ouattara and his supporters. Among other international actors, the independent commission established by the UN Human Rights Council has expressed concern that investigations by the national military and public prosecutors have been limited to former officials and allies of Gbagbo (Baldo 2011; ICG 2011). McGovern (2011), in his detailed anthropological work on the period preceding the post-election crisis "insists on a multicausal explanation of the Ivorian conflict" (p. 25). In doing so, he refuses to accept the tendency of both Ivorian and non-Ivorian analyses to seek "neat" (p. 7) categories of ethnic, religious, and political affiliation which can explain a "victor" and a "loser". However, the dominant discussion among actors both inside and outside of the country is about the nature of the transitional justice process and whether it is biased in favour of Ouattara and his supporters. 
Despite these complexities and contestations, or perhaps because of them, the subsequent transitional justice process was put in place quickly by the new President Ouattara. The Special Inquiry and Investigation Unit on the post-electoral crisis was set up, the Rome Statute was ratified, the International Criminal Court (ICC) began its proceedings and the national courts were activated. ICC indictments for crimes against humanity were issued against Laurent Gbagbo and Charles Blé Goudé. Their cases were joined and then they were both acquitted in February 2020, with the acquittal upheld on March 31, 2021. An ICC indictment was also issued against Gbagbo's ex-wife Simone Gbagbo, who was convicted in the Ivorian national courts to 20 years' imprisonment but who was then released under a 2018 amnesty. Several non-judicial transitional justice institutions were also established, including the Commission dialogue, vérité et reconciliation (CDVR - Truth and Dialogue Commission), the Ministry of Solidarity, Family, Women and Children and its war victims' department, and the National Program for Social Cohesion. Institutional reforms to protect the right to guarantees of non-recurrence and Security Sector Reform were launched and the National Security Council reinstated. Their design and operation met UN standards, but their functioning has been strongly influenced by the political strategies and power games in Côte d'Ivoire (Adou Djané and Jones forthcoming). For example, the final report of the CDVR remained hidden from public scrutiny from 2014 until 2016, and President of the CDVR Konan Banny is a controversial figure, seen by many to be leveraging his position to gain political weight when he became involved in the 2015 presidential election contest.

These contestations pivot on historical injustices and grievances as well as the specifics of the way in which the conflict ended and transitional justice has been implemented. There are varied resistances that we can observe in response: to the different mechanisms of the transitional justice process; to Ouattara's presidency; to the ICC indictments and now appeal against the acquittal of Gbagbo and Blé Goudé. This resistance, following the 2011 violence, has been located in certain actors and interpreted in particular ways. From the beginning of the transitional justice process, pockets of militia violence have been interpreted by the government and its supporters as attempts, by disgruntled "losers" of the transition, to destabilize the country and disrupt the justice process. However, according to Adou Djané (2017, p. 21), this violence is designed to target the political transition itself, meaning the state and current government. The latter, of course, forms the basis of a transitional justice process, but it is not the same, and this distinction is important.

There are also supporters of the former President, Gbagbo, and members of his political party, the Front Populaire Ivoirien (Ivorian Popular Front), who are seen as unable to accept Ouattara's victory. These actors have boycotted the work of the CDVR and political dialogues (Adou Djané 2017, p. 25). In addition, supporters of Gbagbo in the diaspora have organized 
themselves into organized resistance, publishing leaflets denouncing the current president and demanding transparency of the election results of 2010 (Jones 2017).

These actors - supporters of the former president - are the classic "spoilers" of transitional justice: disgruntled; unable to accept democratic process; afraid of being held accountable for crimes; and unwilling to embrace its "values". Cast as the "losers" of the violence as well as of the transition, it is assumed by domestic and international actors that this is the end of the story. Former regime loyalists are known to want to block political progress, to delegitimize Ouattara's presidency and to avoid justice (Jones 2017). The forms of resistance I have described above - protests, violence, boycotts and public denouncements - are also simply understood to be acts of incivility associated with a "past" of disorder and violence (Jones and Adou Djané 2018). The underpinning narratives about resistance to transitional justice in Côte d'Ivoire are thus (a) that it is motivated by failure to accept the "right" outcome of the elections and of the justice process, and (b) that it is part of a deviant disorder of past violence that has no place in the present justiceseeking process, or in the imagined future of peace and democracy.

However, analysis of the resistance can tell us so much more. It is important to see it above all through the lens of "the continuity of violence that characterises the political system" (Adou Djané 2017, p. 17) and thus to understand it as "continual doubting of the political and social contract to which the current transitional justice process has been appended" (p. 17). The complex history of socio-political crises related to citizenship, autochthony and economic collapse in Côte d'Ivoire (Akindès 2004) finds a focal point in and through transitional justice, so while labelling acts of resistance by the election "losers" is an easy interpretation of events, it also reproduces the (partial) narrative of those who are resisted. In my research I have found that those who resist do, in fact, connect their actions to bigger questions of historical standing: "all those in love with justice and democracy must resist" (Zokou 2012), or "Alassane Dramane Ouattara was forced on Côte d'Ivoire by the French army" (Interview 260314F). Interestingly, their counter-narrative echoes similar concerns raised by more "moderate" voices over the transparency of the UN when declaring Ouattara the winner, the lack of transparency of the work of the CDVR, or the bias in prosecutions against supporters of Gbagbo (Jones 2017, p. 47), which makes it even more problematic to simply discount it as not based on facts.

The supposed acts of resistance against transitional justice in fact tell us that the transitional justice process has not been, and perhaps cannot be, able to fully reveal the violence and the contexts which led to it. The focus on specific acts of violence following the 2010 election precludes a larger discussion about the involvement of the former colonial power France, about the historical exclusion of certain ethnic groups from political power and about the distribution of wealth and land in the country. Now that many of the mechanisms have finished their work, including the CDVR, the 
contestations continue. The decision by the ICC to lift the travel restrictions on Gbagbo and Blé Goudé led to the observation that "[o]nce again, the International Criminal Court is upending Ivorian politics" (Africa Confidential 2020). This decision put pressure on the presidential election of October 2020, which was won by Ouattara amid controversy over his "third term", boycotts from the opposition, and violence. ${ }^{4}$ The limits of Ouattara's reconciliation, based on economic recovery and stability through decisive action from the centre of presidential power (N'Da and Fokou 2021), will be tested, as will the limits of a hastily completed and certainly limited transitional justice process.

\section{Concluding remarks}

There is a central contradiction in dominant transitional justice discourse and practice. There is a desire to seek the truth and to claim it when found, while at the same time specific transitional justice mechanisms and processes are necessarily incomplete. This may be due to a selective mandate which looks at violent acts committed between a certain range of dates or by particular actors. It may be due to its instrumentalization by varied actors with particular agendas. It may also be because of the impulse to agree on one narrative, which can unify and form the basis of a future of peace. Such selective politics of knowledge can be enriching and valuable if we can find ways of reading them and understanding what they communicate. In this chapter I have tried to show how resistance can highlight the usefulness of not knowing, of demonstrating the incompleteness of attempts, through transitional justice, to order and categorize the past and to shed a light on diverse experiences and diverse perspectives on the ways forward.

At the beginning of this chapter, I outlined some well-known critiques of transitional justice. I agree with Colvin's (2008, p. 424) assessment that the field does not need yet more knowledge; instead, it needs to rethink its failed relationship to the "other'. In the case of Côte d'Ivoire, more assessments of transitional justice mechanisms and their impacts, while important, do not necessarily help to overcome the frames of reference set by transitional justice discourse and practice. If we stay within the "naturalness and inevitability" of transitional justice (Sharp 201, p. 1), claims to knowledge about the past are less easy to critique. Transitional justice processes and experts all too often make claims to know what happened, how it should be addressed and what kind of future should result. Frequently, there is limited space to recognize what is not known, or what maybe cannot ever be known. Resistance, if nothing else, reminds us that all knowledge of the past is incomplete. I argue that in order to create a more ethical relationship with "the other" with alleged "spoilers", "bad losers" or "unthankful beneficiaries" - humility is fundamental. It allows transitional justice "experts" to begin their work with acknowledging what is not known and what can be learnt from listening to others. Such a process is not easy, as the discussions about inclusivity by 
Vollhardt et al. in Chapter 12 of this volume demonstrate. Learning from resistance is but one way of opening dialogue. It can be difficult because of the perceived "incivility" of those who resist (Jones and Adou Djané 2018), or because of an expected clash of values. But dialogue does not have to be easy to ensure that we are attentive to ongoing efforts to learn from the past rather than seeking to close it down.

\section{Notes}

1 www.ohchr.org/EN/Issues/RuleOfLaw/Pages/TransitionalJustice.aspx.

2 The fieldwork was conducted in 2014 in collaboration with Dit Fatogoma Adou Djané based at the Centre Suisses de Recherches Scientifiques in Abidjan, but I take sole responsibility for the reflections presented in this chapter.

3 The fieldwork was generously funded by the Swiss National Science Foundation as part of the project 'Resisting Transitional Justice? Alternative Visions of Peace and Justice' which ran from 2012-2015.

4 www.hrw.org/news/2020/12/02/cote-divoire-post-election-violence-repression.

\section{References}

Adou Djané, Dit Fatogoma. "Resistance to transitional justice in the context of political violence in Côte d'Ivoire". Resistance and transitional justice, edited by Briony Jones and Julie Bernath, Routledge, 2017, pp. 17-34.

Adou Djané, Dit Fatogoma, and Briony Jones. "Commission of Dialogue, Truth and Reconciliation," Encyclopedia of Transitional Justice: Second Edition, edited by Lavinia Stan and Nadia Nedelsky, Cambridge University Press, forthcoming.

Adou Djané, Dit Fatogoma, and Briony Jones. "Country study: Côte d'Ivoire". Encyclopaedia of transitional justice, edited by Lavinia Stan, Cambridge University Press, forthcoming.

Africa Confidential. Affairs of the state and of the heart. 1 June 2020, www.africa-con fidential.com/article-preview/id/12983/Affairs_of_state_and_of_the_heart. Accessed 1 July 2020.

Akindès, Francis. The roots of the military-political crises in Côte d'Ivoire. Research report No. 128, 2004, Uppsala, Nordiska Afrikainstitutet.

Bah, Abu Bakkar. "Democracy and civil war: Citizenship and peacemaking in Côte d'Ivoire". African Affairs, vol. 109, no. 437, 2010, pp. 597-615.

Baldo, Suliman. "Ivory Coast must avoid victor's justice: Podcast with Suliman Baldo". In Focus, no. 3, 2011, http://ictj.org/content/ictj-focus-issue-3.

Bellamy, Alex J., and Paul D. Williams. "The new politics of protection? Côte d'Ivoire, Libya and the responsibility to protect". International Affairs, vol. 87, no. 4, 2011, pp. 825-850.

Bennett, Tom, Eva Brems, Giselle Corradi, Lia Nijzink, and Martien Schotsmans. African perspectives on tradition and justice. Intersentia, 2012.

Campbell, Colm, and Catherine Turner. "Utopia and the doubters: Truth, transition and the law". Legal Studies, vol. 28, no. 3, 2008, pp. 374-395.

Colvin, Christopher J. "Purity and planning: Shared logics of transitional justice and development". The International Journal of Transitional Justice, vol. 2, no. 3, 2008, pp. $412-425$. 


\section{Briony Jones}

Diallo, Youssouf. From Stability to uncertainty: A recent political history of Côte d'Ivoire. Max Planck Institute for Social Anthropology working paper no. 74, 2005, Max Planck Institute.

Evans, Matthew. "Structural violence, socioeconomic rights, and transformative justice". Journal of Human Rights, vol. 15, no. 1, 2016, pp. 1-20.

Hamber, Brandon, and Richard Wilson. "Symbolic closure through memory, reparation and revenge in post-conflict societies". Journal of Human Rights, vol. 1, no. 1,2002 , pp. $35-53$.

Hansen, Thomas Obel. "The vertical and horizontal expansion of transitional justice: Explanations and implications for a contested field". (eds.) Transitional Justice Theories, edited by Susanne Buckley-Zistel, Teresa Koloma Beck, Christian Braun, and Friederike Mieth, Routledge, 2014, pp. 105-124.

International Crisis Group (ICG). A critical period for ensuring stability in Côte d'Ivoire. Africa report no. 176, ICG, 2011.

Jones, Briony. "Seeking a 'just justice': Discursive strategies of resistance to transitional justice in Côte d'Ivoire". Resistance and transitional justice, edited by Briony Jones and Julie Bernath, Routledge, 2017, pp. 35-50.

Jones, Briony, and Julie Bernath. "Introduction: Resistance and transitional justice". Resistance and transitional justice, edited by Briony Jones and Julie Bernath, Routledge, 2017b, pp. 1-16.

Jones, Briony, and Julie Bernath, editors. Resistance and transitional justice. Routledge, 2017a.

Jones, Briony, and Adou Dit Fatogoma Djané. "Reading the 'uncivil' in civil society resistance to transitional justice in Côte d'Ivoire". Political Geography, vol. 67, 2018, pp. 135-144.

Jones, Briony, and Ulrike Lühe. "Knowledge for peace: Transitional justice and the politics of knowledge in theory and practice." Knowledge for peace: Transitional justice and the politics of knowledge in theory and practice, edited by Briony Jones and Ulrike Lühe, Edward Elgar, 2021, pp. 1-19.

Jones, Briony, and Ulrike Lühe. "The politics of knowledge and an African transitional justice: Analysing Africa as a constitutive outside". Routledge handbook on African peacebuilding, edited by Bruno Charbonneau and Niagalé Bagayoko, Routledge, forthcoming.

Kagoro, Brian. "The paradox of alien knowledge, narrative and praxis: Transitional justice and the politics of agenda setting in Africa". Where law meets reality: Forging African transitional justice, edited by Moses Crispus Okello, Chris Dolan, Undine Whande, Nokukhanya Mncwabe, and Stephen Oola, Pambazuka Press, 2012, pp. 4-52.

Kelsall, Tim. "Politics, anti-politics, international justice: Language and power in the Special Court for Sierra Leone". Review of International Studies, vol. 32, no. 4, 2006, pp. 587-602.

Little, Adrian. "The Northern Ireland paradox". The politics of radical democracy, edited by Adrian Little and Moya Lloyd, Edinburgh University Press, 2009.

Madlingozi, Tshepo. "On transitional justice entrepreneurs and the production of victims". The International Journal of Transitional Justice, vol. 2, no. 2, 2010, pp. 208-228.

McAuliffe, Padraig. Transformative transitional justice and the malleability of postconflict states. Edward Elgar, 2017.

McEvoy, Kieran. "Beyond legalism: Towards a thicker understanding of transitional justice”. Journal of Law and Society, vol. 34, no. 4, 2007, pp. 411-440. 
McEvoy, Kieran, and Lorna McGregor. Transitional justice from below: Grassroots activism and the struggle for change. Hart Publishing, 2008.

McGovern, Mike. Making war in Côte d'Ivoire. Hurst and Co., 2011.

Miller, Zinaida. "Effects of invisibility: In search of the 'economic' in transitional justice”. The International Journal of Transitional Justice, vol. 2, no. 3, 2008, pp. 266-291.

Murphy, Colleen. The conceptual foundations of transitional justice. Cambridge University Press, 2017.

Nagy, Rosemary. "Transitional justice as global project: Critical reflections". Third World Quarterly, vol. 29, no. 2, 2008, pp. 275-289.

N'Da, Serge Alain, and Gilbert Fokou. "Knowledge asymmetry and transitional justice in Côte d'Ivoire". Knowledge for Peace: Transitional justice and the politics of knowledge in theory and practice, edited by Briony Jones and Ulrike Lühe, Edward Elgar, 2021, pp. 75-98.

Nouwen, Sarah M. H. “'As you set out for Ithaka'. Practical, epistemological, ethical, and existential questions about socio-legal empirical research in conflict". Leiden Journal of International Law, vol. 27, no. 1, 2014, pp. 227-260.

Office of the High Commissioner for Human Rights. Special Rapporteur on the promotion of truth, justice, reparation and guarantees of non-recurrence. 2020. www. ohchr.org/EN/Issues/TruthJusticeReparation/Pages/Index.aspx. Accessed 14 April 2020.

Palmer, Nicola, Briony Jones, and Julia Viebach. "Introduction: Ways of knowing atrocity: A methodological enquiry into the formulation, implementation, and assessment of transitional justice". Canadian Journal of Law and Society, vol. 30, no. 2, 2015, pp. 173-182.

Rubli, Sandra. Transitional justice: Justice by bureaucratic means?swisspeace working paper, 2012, www.files.ethz.ch/isn/154626/WP4_2012.pdf. Accessed 14 April 2020.

Salehi, Mariam. "Political resistance: How cross-cutting frictions drive and define transitional justice in Tunisia". Justice Info, 17 July 2018, www.justiceinfo.net/en/justi ceinfo-comment-and-debate/opinion/38036-political-resistance-how-cross-cutting-fricti ons-drive-and-define-transitional-justice-in-tunisia.htm. Accessed 7 December 2018.

Schaap, Andrew. "The time of reconciliation and the space of politics". Law and the politics of reconciliation, edited by S. Veitch, Ashgate, 2007.

Sharp, Dustin N. "Interrogating the peripheries: The preoccupations of fourth generation transitional justice". Harvard Human Rights Journal, vol. 26, 2013, pp. 149-178.

Sharp, Dustin N. Rethinking transitional justice for the twenty-first century: Beyond the end of history. Cambridge University Press, 2018.

Shaw, Rosalind, Lars Waldorf, and Pierre Hazan. Localizing transitional justice: Interventions and priorities after mass violence. University of Stanford Press, 2010.

Sriram, Chandra L. "Beyond transitional justice: Peace, governance, and rule of law". International Studies Review, vol. 19, no. 1, 2017, pp. 53-69.

Subotić, Jelena. "Bargaining justice: A theory of transitional justice compliance". Transitional justice theories, edited by Susanne Buckley-Zistel, Teresa Koloma Beck, Christian Braun, and Friederike Mieth, Routledge, 2014, pp. 128-143.

Thomson, Susan, and Rosemary Nagy. "Law, power and justice: What legalism fails to address in the functioning of Rwanda's gacaca courts". The International Journal of Transitional Justice, vol. 5, no. 1, 2011, pp. 11-30. 


\section{Briony Jones}

United Nations. Guidance note of the Secretary General: United Nations approach to transitional justice, March 2010, www.un.org/ruleoflaw/files/TJ_Guidance_Note_ March_2010FINAL.pdf. Accessed 30 June 2020.

United Nations. Set of principles for the protection and promotion of human rights through action to combat impunity (E/CN.4/Sub.2/1997/20/Rev.1), 1997, https:// digitallibrary.un.org/record/245520?ln=en. Accessed 14 April 2020.

Weinstein, Harvey M. "Editorial note: The myth of closure, the illusion of reconciliation: Final thoughts on five years as co-editor-in-chief". The International Journal of Transitional Justice, vol. 5, no. 1, 2011, pp. 1-10.

Wilson, Richard A. "Expert evidence on trial: Social researchers in the international criminal courtroom”. American Ethnologist, vol. 43, no. 4, 2016, pp. 730-744.

Zokou, S. Communiqué du presse du Comité de Pilotage des Actions de la Diaspora. 20 September 2012, www.civox.net/Communique-de-presse-du-Comite-de-Pilotage-de s-Actions-de-la-Diaspora-CPAD_a1404.html. Accessed 30 March 2017. 